\title{
'Love the sinner, not the sin?' Sexual and gender diversity in faith communities
}

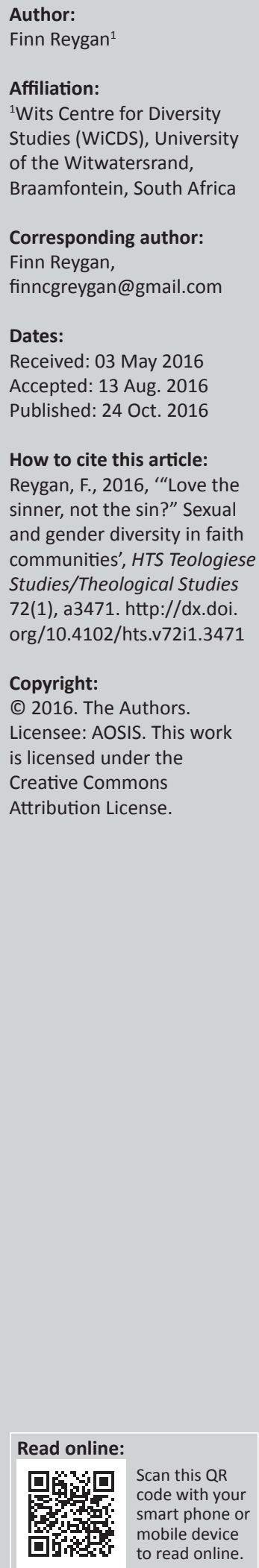

\begin{abstract}
While queer theology has foregrounded sexual and gender diversity in faith communities internationally, in South Africa, the emergence of a queer, African theology is necessary given that religion is often not a 'safe space' for sexual and gender minorities owing to theological violence. Advocacy for inclusion requires the development of theological capacity in queer communities so as to foster biblical, theological and interpretative resistance. There are a number of approaches available, including demythologising and reclaiming the Bible for queer communities, developing more redemptive interpretative options for queer inclusion and developing alternative discourses that challenge the heteropatriarchy of the Bible. Entry points for this work include Bible study; workshops and seminars for faith communities on sexual and gender diversity; the acceptance of a minimum pastoral threshold (or minimum levels of preparedness) for engaging with issues of sexual and gender diversity; and creating ecumenical spaces, cognizant of the local context, where such engagements can take place. This involves moving beyond a theology of compassion and essentialised notions of sexuality and gender so as to develop a queer, African, people's theology that recognises the trauma experienced by sexual and gender minorities in faith communities.
\end{abstract}

\section{Introduction}

A number of recent events - such as 'Homophobia and the churches in Africa: A dialogue' organised by the The Other Foundation in Pietermartizburg, South Africa, in 2016 - point to the growing interest in and the need for interventions across Southern Africa to engage religious leaders and faith communities on issues of sexual and gender diversity. This in turn reflects a growing interest in issues of power, privilege and difference across sectors as explored in the critical diversity studies' literature (Steyn 2015) in South Africa. In 2015, the civil society organisation, Gay and Lesbian Memory in Action has also hosted a series of successful dialogues with religious leaders and faith communities in Gauteng on lesbian, gay, bisexual, transgender and intersex (LGBTI) issues. Furthermore, in 2015, the Institute of Development Studies (IDS) in the United Kingdom, Sonke Gender Justice and the Wits Centre for Diversity Studies (WiCDS) in South Africa convened a pan-African gathering of religious representatives to discuss faith, gender and sexuality, and in April 2015, the toolkit emerging from this process was launched online. In short, there is a growing interest on the part of LGBTI activists in engaging the religious sector on LGBTI rights and inclusion. There is also a tentative but emergent desire in faith communities to understand more about the lives of previously invisible and marginalised LGBTI populations.

These dialogues and convenings are important for a number of reasons: they indicate that LGBTI advocacy is realising the importance of engaging the previously ignored religious sector; the effects of homophobia, including religious homophobia, on the health and well-being of LGBTI populations are increasingly being documented; and the engagement with church leaders and faith communities by queer activists is apparently one way to challenge beliefs that sexual and gender diversity are 'unAfrican', 'unChristian' and not part of culture. However, successful dialogue with faith communities on these issues will have at least two key prerequisites: the development of appropriate materials and processes so as to facilitate this sensitive dialogue to take place, and an engagement with the contextual theology that has emerged in recent years from sexual and gender minorities. As a result, this article asks: What theological approaches and material are available in the southern Africa context to facilitate emerging dialogue between queer activists and faith communities?

\section{Queer theology}

The focus of this article is on (queer) theological content only insofar as it serves the process of engaging religious leaders and faith communities on issues of sexual and gender diversity. 
Therefore, more nuanced queer, theological reflections can be found in the sources cited in the paper. This paper also takes as a given that sexual and gender minorities have a right of belonging and participation in their faith communities and that their exclusion is an ongoing form of discrimination. Another given is that there can be no dialogue around sexual and gender diversity without LGBTI participation, just as conversations about women in religion cannot happen without women's voices. Given the resources presented in this paper, the focusis on Christianity, but this Christonormative approach does not detract from the importance of dialogue around sexual and gender diversity across religions and faith traditions.

Queer theology - which in the context of this paper is understood as an umbrella term for marginalised sexual and gender identities - has emerged in recent years, following on the heels of Latin American liberation theology, feminist theology and African women's theology (see Phiri \& Nadar 2006). It is a contextual theology that speaks directly to the lived experiences of sexual and gender minorities and, like other theologies that work from the perspective of and along with the marginalised and oppressed, queer theology foregrounds the often traumatic experiences of LGBTI people in and outside religion. This epistemological privileging of the embodied experiences and knowledge of oppressed people lies at the heart of queer theology and reflects the emergence of a politics of liberation for sexual and gender minorities around the globe in recent years. This global call to arms for sexual and gender minority rights is manifest in the United Nation's recent 'Love Not Hate Campaign' and in the institutionalisation of 'gay rights' in South Africa's Constitution.

Theoretically, queer theology is inflected by and grounded in queer theory and queer sociology (see Butler 2011; Foucault 1977; Rubin 1992; Sedgwick 2015) in the West and provides queer perspectives on religion and spirituality (cf. Cheng 2011, 2013). It offers a queer interpretation of Christian theology and offers LGBTI individuals and communities a 'safe space' to engage with and talk about religion. Both queer theory and its theological application are inherently transgressive in their social constructionist challenge to societal, binaried and essentialising norms. Queer theory references gender variance and non-normative sexualities and functions as a critique, questioning and resisting dominant, hegemonic norms that, while presented as transhistorical and natural, are socially and historically contingent. Historically, initial scholarship on a budding gay theology was developed by Clarke, Brown and Hochstein (1992) followed by seminal work on a nascent queer theology by Goss (1994) and were driven by the notion that nonnormative sexualities and genders have been present throughout history and that they find expression in sacred texts, including the Bible.

Queer theology is a theology for and by LGBTI people, focused on their needs, that talks about the divine in a purposefully transgressive manner in relation to societal norms around gender and sexuality (see Cheng 2011). It is an avowedly liberatory theology that attempts to unearth the experiences, knowledge and beliefs of voices that have been erased and marginalised. Reflecting its base in queer theory, queer theology is part of the project to erase boundaries and challenge the supposedly natural and binaried categories on which society is constructed, such as male/female, black/ white and gay/straight. For example, the late Marcella Althaus-Reid (2002, 2003), informed by Latin American liberation theology, developed a biblical exegesis that foregrounds the lived realities of women, the marginalised and queer communities - a theology premised on the centrality of lived experience and the body:

Only in the longing for a world of economic and sexual justice together, and not subordinated to one another, can the encounter with the divine take place. But this is an encounter to be found at the crossroads of desire, when one dares to leave the ideological order of the heterosexual pervasive normative. This is an encounter with indecency, and with the indecency of God and Christianity. (Althaus-Reid 2002:200)

The work of Althaus-Reid (2003) explored the realities of queer subcultures, including the sanctity of secular gay spaces such as gay bars, and in so doing engaged with the possibilities of imbricated faith and desire. In his obituary for Althaus-Reid, Jay Emerson Johnson (2014) elucidates the transgressive and inclusive qualities of queer theology:

'Queer theology' has been bubbling up in some quarters for a while now, but not quite as long as 'queer theory'. Both spark considerable controversy, and sometimes for similar reasons ... In religious circles, gay and lesbian people have been working for decades to carve out a 'place at the table' in faith communities that they so rightly deserve. The work can be slow and arduous, which the word 'queer' - some strenuously insist - can derail ... It simply perpetuates [some argue] the assumption that we're different [but] ... [t] hat's exactly the point, as Marcella AlthausReid would have chimed in had she been there. We are different. And the only way to do Christian theology is from that place of difference. The 'we' for Althaus-Reid didn't mean only lesbian and gay people, nor the ones so quickly added on later, like bisexuals and transgender folks. 'We' are all those who don't fit the regulatory regimes of both state and church marked by gender, sexuality, race, ethnicity, class, and economics. For her, 'queer' maps out a space of resistance to those regimes, not just to oppose but creatively to construct, re-imagine, and envision a different kind of world. (Johnson n.d.)

Religious homophobia gains much of the attention in the literature and, for example, Lease, Horne and NoffsingerFrazier (see 2005) argue that discrimination is so widespread in churches that LGBTI identities and religious practice are often seen as mutually exclusive. The literature also points to the detrimental impact of religion on the psychological wellbeing of LGBTI people which is compounded by opposition to openly gay religious officials, hostile teachings on homosexuality and the general marginalisation of LGBTI people in religion (see Gage Davidson 2000; Mahaffy 1996; Rodriguez \& Ouellette 2000). Other research points to the ways in which alternative, nature-based traditions such as 
Wicca, paganism and shamanism may be more inclusive of sexual and gender minorities (see Smith \& Horne 2007). However, it also appears that the sexual and gender minorities are increasingly attracted to more affirming and personal forms of spirituality (see Lease et al. 2005). There is also substantial research by Yip (2005) on the pathways of sexual and gender minorities in relation to religious opprobrium as well as the strategies that sexual and gender minorities develop to deal with rejection from faith communities. In short, while the religious lives of LGBTI people continue to be challenging in many ways, growing trends in religious studies, theology and the social sciences more generally have begun to engage in a more nuanced way with these lived realities. This is occurring in tandem with the emergence of denominations specifically for sexual and gender minorities - such as the Metropolitan Community Church (MCC) which has a presence in South Africa and Inclusive and Affirming Ministries (IAM) - in the broader context of a growing, global LGBTI rights movement with attendant backlash.

The scholarship on African sexualities explores the ways in which non-normative sexualities and genders have - and continue to be - constructed, represented and lived in communities across the continent, including in relation to religion and faith communities (see among others: Epprecht 2004; Matebeni 2014; Msibi 2011; Nyanzi 2013; Tamale 2011). In terms of faith communities, 'Aliens in the household of God: Homosexuality and Christian faith in South Africa' by Germond and De Gruchy (1997) was one of the first texts to comprehensively engage with issues of sexual and gender diversity in faith communities in South Africa and has been fundamental in developing a queer, African theology. This project has some notable allies, including Archbishop Tutu who famously declared that he would not worship a homophobic God (Mail \& Guardian 2007). The growing research also includes an analysis of the texts of queer churches such as the MCC (see Potgieter \& Reygan 2011), the Ujamaa Centre at the University of KwaZulu-Natal is leading on deepening related scholarship, and an important case was brought to the South African Constitutional Court by Rev Ecclesia de Lange (Watson 2015) of the Methodist Church of South Africa (MCSA). Therefore, while many religious traditions in southern Africa continue to be characterised by heteropatriarchy, LGBTI people are beginning to claim religious space for themselves.

This growing body of knowledge and activism globally and in South Africa is important because religion is often not a 'safe space' for many sexual and gender minorities owing to theological violence. Therefore, the question at the start of this paper remains relevant: What theological approaches and material supports are available in the Southern Africa context to facilitate emerging dialogue between queer activists and faith communities? In response, it is apparent that such spaces and advocacy for inclusion require the development of the theological capacity of queer communities in terms of biblical, theological and interpretative resistance.
In this regard, a number of resources have recently been developed in the Southern African context that speak for the need to create safe spaces and appropriate support materials for engaging faith communities on issues of sexual and gender diversity. One such resource was developed by the IDS in the United Kingdom and by Sonke Gender Justice and the WiCDS in South Africa, in partnership with faith communities and religious leaders from across the continent.

\section{Queer faith diversity toolkit}

Increasing knowledge about the links between sexuality, gender and faith is a vital step in tackling the social injustices that affect millions of people globally, and faith leaders have a critical role to play in influencing attitudes, culture and policy. (Mills 2016)

Religion plays a key role globally in relation to social norms around gender and sexuality and a resource entitled 'Faith, Gender \& Sexuality Toolkit' developed by IDS, Sonke and WiCDS aims to inform and provide support for faith communities and religious leaders who wish to engage in an affirming way on issues of sexual and gender diversity. The toolkit challenges some of the common myths surrounding sexual and gender diversity and provides alternative ways for faith communities to think about sexual and gender diversity, particularly in terms of advancing a human rights agenda. The authors of the resource view both culture and tradition as dynamic and open to re-interpretation and reinvention and the toolkit contains six modules and faithbased case studies on a range of issues including: genderbased violence; sexual diversity; sexual and reproductive health rights; and women, gender and power. The authors also frame sexual and gender diversity issues in religion around broader human rights issues and social inclusion:

... having a sexual orientation or gender identity that does not
conform to the majority norm can affect one's ability to earn a
livelihood and gain employment, access education and
healthcare, form the family and personal relationships that you
desire, live free from violence and harassment, and seek justice
through the law. Sexual rights embrace human rights that are
already recognised in national laws, international human rights
documents and other consensus documents. Like heterosexual
people, lesbian, gay, bisexual and trans people are entitled to the
same rights as those of other human beings. (http://www.ids.
ac.uk/news/new-interactive-resource-to-bridge-gap-between-
faith-gender-and-sexuality)

In terms of general sensitisation work with religious leaders and faith communities around issues of sexual and gender diversity, the authors of the toolkit suggest keeping the following in mind (see Box 1).

The toolkit becomes particularly useful in engaging faith communities on issues of sexual and gender diversity when it presents examples of queer exegesis. This is seen in the following exercises that firstly present a biblical passage often used to exclude LGBTI people - such as Genesis and Sodom and Gomorrah - followed by forms of queer, interpretative theological resistance (see Figure 1). 
The novelty of this approach - of capacitating queer communities to engage in theological discourse - is that it involves using the 'master's voice' (religious language and knowledge of the Bible) to speak back to religious homophobia. Another text that is widely cited to justify homophobia is Genesis and this too is reinterpreted in the toolkit (see Figure 2).

The toolkit was conceptualised through engagement with faith community representatives from across the continent. This stakeholder engagement (see Marks et al. 2015) highlighted numerous challenges when attempting to foster dialogue on sexual and gender diversity in faith communities. These challenges included: a general lack of knowledge and understanding about the issues; a paucity of materials on the topic; concern about the implications of engaging faith communities in such dialogue; pervasive heteronormativity; the policing of non-normative sexualities and genders in faith communities; and that patriarchy, cultural norms and violence continue to be employed to subjugate women and sexual and gender minorities. The envisaged outcomes of the use of this toolkit are the development of queer, interpretative and theological resistance on the part of queer communities engaging in exegesis as a form of activism with faith communities. The toolkit also attempts to close the knowledge gap in faith communities about sexual and gender diversity and about the ways in which faith communities can become welcoming and affirming spaces.

BOX 1: Suggestions for working with faith communities on queer issues.

- Biblical writers did not share our contemporary understanding of gender and sexual diversity

- Any same-sex behaviour that biblical writers may have witnessed was either outside the bonds of heterosexual marriage (and so also viewed as adulterous and a sin) or outside the community of faith (and so associated with idolatry or 'pagan' faiths). It was therefore 'double-stigmatised'.

- Same-sex expression was condemned largely for crossing boundaries of gender: specifically, men viewed as abandoning their active role in intercourse to be passive with other men (as in Leviticus) and women perceived as abandoning their passive role to be active with women (as in Romans where the word for 'marriage' literally means 'under a man').

- Homosexuality was frequently confused with pederasty, the practice of men using boys for sexual pleasure. The King James Version (KJV) of the Bible has frequent references to 'sodomites'; more recent translations avoid this term because the word, when originally translated, referred to male pagan priests. Similarly, the word for pagan priestess was incorrectly translated as 'prostitute'. Ironically, historians have much evidence that King James, who first authorised the translation of the Bible into English, was himself homosexual.

- Jesus never condemned homosexuality but challenged divorce, wealth, spiritual pride and exclusion.

(http://spl.ids.ac.uk/sexuality-gender-faith/sexuality-and-gender-diversity/case-studies/1-approaching-bible)

Source: http://spl.ids.ac.uk/sexuality-gender-faith/sexuality-and-gender-diversity-overview

\section{Creation: Genesis 1:27-28; 2:18, 21-25 \\ So God created humankind in his image, in the image of God he created them; male and female he created them. God blessed them and God said to them, 'Be fruitful and multiply, and fill the earth and subdue it; and have dominion over the fish of the sea and over the birds of the air and over every living thing that moves upon the earth'. Then the Lord God said, 'It is not good that the man should be alone; I will make him a helper as his partner'. So the Lord God caused a deep sleep to fall upon the man, and he slept; then he took one of his ribs and closed up its place with flesh. And the rib that the Lord God had taken from the man he made into a woman and brought her to the man. Then the man said, 'this at last is bone of my bones and flesh of my flesh; this one shall be called Woman, for out of Man this one was taken'. Therefore a man leaves his father and his mother and clings to his wife, and they become one flesh. And the man and his wife were both naked, and were not ashamed.}

\section{Interpretation}

There are two creation stories, one in Genesis 1, and the other in Genesis 2. The first story is about the creation of the cosmos, the second about the first human beings: thei curiosity, frailties and relationship to earth. The second also explains humanity's relationship to God and each other - it is not just about marriage. Christian traditions hold that there is much more in these two creation stories than marriage and that the stories serve a twofold purpose. In the first story, the purpose is 'to be fruitful and multiply' - in other words, the purpose of marriage is procreation. Roman Catholic tradition emphasises this, though in the latter half of the 20th century, canon law was changed to acknowledge that marriage may exist between persons who cannot have children. In the second story, the more ancient of the two, the purpose of marriage is companionship - to find a suitable partner. This is the story that Jesus quotes to refute divorce: the two become one in marriage. Protestant tradition recognises both procreation and companionship as equal validations of marriage. Today, same-gender couples are capable of having and rearing children. Same-gender couples have always been capable of companionship and mutuality, which is the purpose of marriage that Jesus highlighted in Matthew 19:3-12.

(http://www.ids.ac.uk/news/new-interactive-resource-to-bridge-gap-between-faith-gender-and-sexuality)

Source: http://spl.ids.ac.uk/sexuality-gender-faith/sexuality-and-gender-diversity-overview

FIGURE 1: Genesis exercise.

\section{Sodom and Gomorrah: Genesis 19:4-5}

But before they lay down, the men of the city, the men of Sodom, both young and old, all the people to the last man, surrounded the house, and they called to Lot, 'Where are the men who came to you tonight? Bring them out to us, so that we may know them'.

\section{Interpretation}

Taken together (in context), the 18th and 19th chapters of Genesis serve as contrasting stories about hospitality. Jews do not separate these stories. In Genesis 18 , Abraham and Sarah 'entertain angels unawares' when they invite three strangers to join them for food and drink, one of whom turns out to be God and the other two angels. Hospitality in the wilderness was not merely a courtesy; it was a moral requirement to offer food, drink and shelter. By extending such hospitality, Abraham and Sarah learn that they would have a son in their old age, and, after the two angels depart for Sodom, God confides in Abraham the plan to destroy Sodom for its wickedness. Abraham bargains God down from 50 righteous men needed to prevent the disaster down to 10 . When all the men of the city surround Lot's house demanding to gang rape the two strangers, refusing Lot's offer of righteous men needed to prevent the disaster down to 10. When all the men of the city surround Lot's house demanding to gang rape the two strangers, refusing Lot's offer of his own daughters to protect them, it is clear there are not 10 righteous men in the city, sealing
biblical interpretations of Sodom's sin, see also Ezk 16:49; Am 4:1, 11; Is 1:10-17; Mt 10:14-15.)

(http://www.ids.ac.uk/news/new-interactive-resource-to-bridge-gap-between-faith-gender-and-sexuality) 


\section{Conclusion}

This article began with a question: What theological approaches and material supports are available in the southern Africa context to facilitate emerging dialogue between queer activists and faith communities? In this regard, it is apparent that non-normative sexualities and genders have become a new site of struggle, both globally and across the African continent. This new contestation foregrounds the omnipresence of heteropatriarchy and the effect this has on the lives and bodies of women and of sexual and gender minorities in diverse cultural and social contexts. In the religious sphere in Africa, the multiple ways in which theology can be applied to issues of non-normative sexualities and genders are yet to become fully apparent. What is clear is that safe space is a necessary prerequisite for the work of developing a queer, African theology because LGBTI people continue to experience trauma in faith communities owing to religious homophobia.

This article presents one particular approach to facilitating dialogue between queer activists and faith communities, which is the re-reading of 'toxic' texts so as to demythologise and reclaim the Bible for queer communities. Toxic texts may be understood as those religious texts that have been used historically to vilify and alienate queer people. Inherent in this process is the development of more redemptive interpretative options for LGBTI inclusion as alternative discourses that challenge the heteropatriarchy of the Bible. There are also multiple methodologies and entry points for this work, including Bible study; the development of 'safe spaces'; queer liturgy; queer prayers; workshops or seminars for faith communities on sexual and gender diversity; the acceptance of a minimum pastoral threshold for engaging with issues of sexual and gender diversity; and creating ecumenical spaces, cognisant of local context, where such engagements can take place. Inherent in these approaches is the necessity of moving beyond a theology of compassion and essentialised notions of sexuality and gender so as to develop a queer, African, people's theology that recognises the trauma experienced by sexual and gender minorities in faith communities.

\section{Acknowledgements}

The author wishes to thank the organisations mentioned in this article who are doing important work in the area: The Other Foundation; the Institute of Development Studies (IDS); Sonke Gender Justice; the Ujamaa Centre; Gay and Lesbian Memory in Action (GALA); and the Wits Centre for Diversity Studies (WiCDS).

\section{Competing interests}

The author declares that he has no financial or personal relationships which may have inappropriately influenced him in writing this article.

\section{References}

Althaus-Reid, M., 2002, Indecent theology: Theological perversions in sex, gender and politics, Routledge, London.

Althaus-Reid, M., 2003, The queer God, Routledge, New York.

Butler, J., 2011, Gender trouble: Feminism and the subversion of identity, Routledge, New York.

Cheng, P., 2011, An introduction to queer theology: Radical love, Church Publishing, New York.

Cheng, P., 2013, Rainbow theology: Bridging race, sexuality, and spirit, Seabury Books, New York.

Clarke, J.M., Brown, J.C. \& Hochstein, L.M., 1989, Institutional religion and gay/ Lesbian oppression, Marriage \& Family Review 14, 265-284. http://dx.doi. org/10.1300/J002v14n03_13

Epprecht, M., 2004, Hungochani: The history of a dissident sexuality in Southern Africa, McGill-Queens University Press, Montreal.

Foucault, M., 1977, Discipline and punish: The birth of the prison, Vintage, New York.

Gage Davidson, M., 2000, 'Religion and spirituality', in R.M. Perez, K.A. DeBord \& K.J. Bieschke (eds.), Handbook of counseling and psychotherapy with lesbian, gay, and bisexual clients, pp. 409-433, American Psychological Association, Washington, DC.

Germond, P. \& De Gruchy, S., 1997, Aliens in the household of God: Homosexuality and Christian faith in South Africa, New Africa Books, Cape Town.

Goss, R., 1994, Jesus acted up: A gay and lesbian manifesto, Harper, San Francisco, CA.

Johnson, J.E., n.d., 'Queer saints and martyrs (and others)', viewed 10 August 2016, from http://queering-the-church.blogspot.co.za/2012/02/rememberingmarcella-althaus-reid.html

Johnson, J.E., 2014, Peculiar faith: Queer theology for Christian witness, Church Publishing Inc, New York.

Lease, S., Horne, S. \& Noffsinger-Frazier, N., 2005, 'Affirming faith experiences and psychological health for Caucasian lesbian, gay, and bisexual individuals', Journal of Counseling Psychology 52, 378-388. http://dx.doi.org/10.1037/0022 0167.52.3.378

Mahaffy, K.A., 1996, 'Cognitive dissonance and its resolution: A study of lesbian Christians', Journal for the Scientific Study of Religion 35, 392-402. http://dx.doi. org/10.2307/1386414

Mail \& Guardian, 2007, 'Tutu blasts Anglican church for gay obsession', 18 November viewed 10 August 2016, from http://mg.co.za/article/2007-11-18-tutu-blastsanglican-church-for-gay-obsession

Marks, B., Charles, T., Mills, E. \& McEwen, H., 2015, Religion, gender and sexuality workshop report, evidence report N.162, sexuality, poverty and law, viewed 10 August 2016, from http://www.ids.ac.uk/publication/religion-gender-andsexuality-workshop-report-1-5-june-2015-garden-court-hotel-eastgatesexuality-works
johannesburg

Matebeni, Z., 2014, Reclaiming Afrikan: Queer perspectives on sexual and gender identities, Modjaji Books, Cape Town.

Mills, E., 2016, 'New interactive resource to bridge gap between faith, gender and sexuality', in Faith, gender and sexuality: A toolkit for practitioners, viewed 10 August 2016, from http://www.ids.ac.uk/news/new-interactive-resource-tobridge-gap-between-faith-gender-and-sexuality

Msibi, T., 2011, 'The lies we have been told: On (homo) sexuality in Africa', Africa Today 58, 54-77. http://dx.doi.org/10.2979/africatoday.58.1.55

Nyanzi, S., 2013, 'Dismantling reified African culture through localized homosexualities in Uganda', Culture, Health \& Sexuality 15, 952-967. http://dx.doi.org/10.1080/1 3691058.2013.798684

Phiri, I.A. \& Nadar, S., 2006. 'What's in a name? Forging a theoretical framework for African women's theologies', Journal of Constructive Theology 12(2), 5-24.

Potgieter, C. \& Reygan, F., 2011, 'Disruptive or merely alternative? A case study of a South African gay church', Journal of Gender and Religion in Africa 17, 58-76.

Rodriguez, E.M. \& Ouellette, S.C., 2000, 'Gay and lesbian Christians: Homosexual and religious identity integration in the members and participants of a gay-positive church', Journal for the Scientific Study of Religion 39, 333-347. http://dx.doi. org/10.1111/0021-8294.00028

Rubin, G., 1992, 'Of catamites and kings. Reflections on butch, gender, and boundaries', in J. Nestle (ed.), The Persistent Desire: A Femme-Butch Reader, pp. 466-482, Alyson, Boston, MA.

Sedgwick, E.K., 2015, Between men: English literature and male homosocial desire, Columbia University Press, New York.

Smith, B. \& Horne, S., 2007, 'Gay, lesbian, bisexual, and transgendered (GLBT) experiences with Earth-spirited faith', Journal of Homosexuality 52, 235-248. http://dx.doi.org/10.1300/J082v52n03_11

Steyn, M., 2015, 'Critical diversity literacy: Essentials for the twenty-first century', in S. Vertovec (ed.), Routledge international handbook of diversity studies, pp. 379-389, Routledge, New York.

Tamale, S., 2011, African sexualities: A reader, Fahamu/Pambazuka, Cape Town.

Watson, A., 2015, 'Con court blocks lesbian minister', The Citizen, viewed 10 August 2016, from http://www.citizen.co.za/880743/con-court-blocsbian-minister/

Yip, A.K.T., 2005, 'Queering religious texts: An exploration of British nonheterosexual Christians' and Muslims' strategy of constructing sexuality-affirming hermeneutics', Sociology 39, 47-65. http://dx.doi.org/10.1177/0038038505049000 